Measurements of workplace productivity in the office context: A systematic review and current industry insights

\author{
B. Bortoluzzi ${ }^{1}$, D. Carey ${ }^{1}$, J.J. McArthur ${ }^{1}$ and C. Menassa ${ }^{2}$ \\ ${ }^{1}$ Department of Architectural Science, Ryerson University, Toronto, Canada \\ ${ }^{2}$ Department of Civil and Environmental Engineering, University of Michigan, Ann Arbor, \\ Michigan, USA
}

Note: this is the self-archived post-print version of the following article, available online at https://www.emeraldinsight.com/doi/abs/10.1108/JCRE-10-2017-0033.

Bortoluzzi, B., Carey, D., McArthur, J.J. and Menassa, C., 2018. Measurements of workplace productivity in the office context: A systematic review and current industry insights. Journal of Corporate Real Estate, 20(4), pp.281-301. 


\title{
Measurements of workplace productivity in the office context: A systematic review and current industry insights
}

\author{
B. Bortoluzzi ${ }^{1}$, D. Carey ${ }^{1}$, J.J. McArthur ${ }^{1}$ and C. Menassa ${ }^{2}$ \\ ${ }^{1}$ Department of Architectural Science, Ryerson University, Toronto, Canada \\ ${ }^{2}$ Department of Civil and Environmental Engineering, University of Michigan, Ann Arbor, \\ Michigan, USA
}

\begin{abstract}
Purpose - The aim of this paper is to present a comprehensive survey of workplace productivity key performance indicators used in the office context. Academic literature from the past ten years is systematically reviewed and contextualized through a series of expert interviews.

Design/methodology/approach - The authors present a systematic review of literature to identify Key Performance Indicators (KPIs) and methods of workplace productivity measurement, complemented by insights semi-structured interviews to inform a framework for a benchmarking tool. 513 papers published since 2007 were considered, of which 98 full-length papers were reviewed, and 20 were found to provide significant insight and are summarized herein.
\end{abstract}

Findings - Currently, no consensus exists on a single KPI suitable for measuring workplace productivity in an office environment, though qualitative questionnaires are more widely adopted than quantitative tools. The diversity of KPIs used in published studies indicates that a multidimensional approach would be most appropriate for knowledge-worker productivity measurement. Expert interviews further highlighted a shift from infrequent, detailed evaluation to frequent, simplified reporting across human resource functions and this context is important for future tool development.

Originality/value - This paper provides a summary of significant work on workplace productivity measurement and KPI development over the past ten years. This follows up on the comprehensive review by B. Haynes (2007a), providing an updated perspective on research in this field with additional insights from expert interviews.

Keywords: performance measurement, knowledge worker; worker productivity; environmental factor; productivity benchmarking 


\section{Introduction}

In the knowledge worker context, there is increasing interest in improving worker and team productivity, as human resources form the highest share of expenses and generate the majority of the organization's income. Despite significant research correlating indoor environmental conditions on productivity in education and healthcare fields, there is a paucity of research on productivity measurement in the knowledge worker context. Since the last systematic review on this topic (Haynes, 2007), there has been a widespread adoption of information technology has increased the incidence of hoteling/hot-desking, flexible hours, and remote working (Cole, et al., 2014), and encouraged a shift to activity-based workplaces (Wohlers \& Hertel, 2017).

Concurrently, the induction of millennials into the workforce has resulted in a desire for increased feedback frequency (Walden, et al., 2017) shifting appraisals and other performance management from infrequent, punctuated benchmarking to near real-time data acquisition to inform continuous improvement. This literature review contributes to the ongoing discourse regarding workplace productivity, providing new insights both from the literature and from interviews with industry experts to provide an up-to-date holistic perspective on productivity measurement of knowledge workers.

Several sectors have widely-adopted productivity measurements. In the manufacturing industry, productivity measurement is clearly established based on production goals through the number of widgets (or other outcome) completed over a set period of time (Brynjolfsson, 1993). Substantial effort has also been expended to develop KPIs and metrics for productivity in the construction (Thomas, 2015), healthcare (Walker, et al., 2017), and education sectors (Heschong, 1999). Industry-specific metrics for those contexts have been developed but few efforts (notably the White-Collar Index study by (Miller, et al., 2009)) have addressed the knowledge worker context. Labour productivity quantification is challenging because, as noted by Thomas (2015) it “is unique in that there is no single KPI that can be used to define best performance.” A multifactor and multi-dimensional approach is thus required, providing a complex research problem to be addressed in this project.

There exists no agreed singular KPI for office worker productivity - in fact, the identification of a single factor has been dubbed the search for the "Holy Grail” (Haynes \& Price, 2004). However, significant trends in the academic literature provide insight on a breadth of key 
performance indicators, their underlying data sources, approaches to their measurement, and the environmental factors that may affect them. A breadth of approaches to quantify productivity have been proposed, including standardized performance tests (Guo, et al., 2014), standardized tests of emotional states, self-assessment (Feige, et al., 2013; Roelofsen, 2002), bio-physical measures tests (Guo, et al., 2014), job statistics (e.g. billable hours, quantified outputs, absenteeism rates), and observed behavior (Reeve, 2014).

\subsection{Definitions}

There is a lack of consistency on the use of the terms "KPIs" and "factors" in the academic literature and thus these terms have been specifically defined in this study:

1. A Key Performance Indicator (“KPI”) is a metric representing an actual or perceived level of work completion or lack thereof. KPIs are dependent variables and may change in response to a change in one or more contributing factors.

2. A contributing factor ("factor") is any physical, organizational, environmental, or social element that affects a worker's ability to perform their tasks. While these often depend on other factors, they are independent of KPIs.

\subsection{Research Objective and Supporting Questions}

The overall goal of this research is to identify trends in contemporary academic literature to inform future productivity measurement tool development. The following three research questions were used to guide this analysis.

1. What field measurement techniques, established tools, and data sources are most widely used to quantify KPIs?

2. What are the KPIs considered in contemporary research to measure workplace productivity?

3. What contributing factors have been considered within existing tools and show the most significant correlations?

Together, these questions provide insight on the breadth of potential means of measuring workplace productivity, which can be used to develop sophisticated, multidimensional tools suitable for the contemporary office workplace. 


\subsection{KPI Types and Data Sources}

KPIs can be classified using a two-dimensional classificatory scheme similar to that used by Haynes (2007) to evaluate overall business performance. The first dimension considers the type of data measuring performance: financial, organizational, environmental, and worker input. The second dimension identifies the types of data sources, which are defined as qualitative or quantitative. This classificatory scheme is illustrated in Figure 1.

\begin{tabular}{|c|c|}
\hline Types of Data \\
Task-Based Performance \\
(e.g. rate of work completion) \\
\hline $\begin{array}{c}\text { Worker Input } \\
\text { (e.g. self-assessment) } \\
\text { (e.g. absenteeism rates) }\end{array}$ \\
\hline $\begin{array}{c}\text { Financial } \\
\text { (e.g. billable hours) }\end{array}$
\end{tabular}

Figure 1 Proposed two-dimensional classificatory scheme

The papers reviewed identified a wide range of potential contributors to performance and the data sources that could be used for KPI measurement and have been grouped thematically (behavioral, organizational, and building environment factors). This review focuses on distilling these down to the major KPIs found within the literature, and the correlation of these with industry trends. Based on the classification scheme, a theoretical model is proposed in the conclusion of this paper to relate the effect of underlying factors to KPIs and potential approaches to measurement.

\subsection{Contributing Factors}

Several factors are known to affect worker productivity under controlled conditions and a significant number of papers include these enabling/hindering factors as key performance indicators in their studies. These include: social factors (Leaman \& Bordass, 1999; Oseland \& Bartlett, 2000; Haynes, 2007), environmental factors, such as indoor air quality (Feige, et al., 2013; Wyon, 2004; Wargocki, et al., 2000), lighting levels and characteristics (Juslén, et al., 2007), acoustic conditions (Roelofsen, 2002; Tiller, et al., 2010), access to daylight and views (Heschong, 1999; Choi, et al., 2012), and maintenance of thermal comfort (Seppänen, et al., 2004; Guo, et al., 2014). There is an assumption inherent in several of the reviewed papers that 
the achievement of such enablers is directly correlated with improved productivity and this study presents those elements most commonly confounded as both enabling factors and KPIs.

\section{Methodology}

Two sources of data were considered in this study: a systematic review of the literature, and a series of semi-structured interviews with industry experts working on workplace productivity improvement in the office context.

\subsection{Literature Review Methodology}

The literature review was completed in a multi-stage process following PRISMA guidelines (Moher, et al., 2010), as illustrated in Figure 2. Because neither Haynes (Haynes, 2007) nor other previous reviews have explicitly stated their article sources, a broad range of databases were searched: multi-disciplinary databases with varied international focuses (Annual Reviews, Emerald, JSTOR, Oxford Journals, Proquest, Scholar's Portal, Scopus, Springerlink) supplemented by health-oriented (Ovid, OSHLINE, Biomed Central) and science-oriented databases (Science Direct, Web of Science). The search terms used were \{"workplace productivity" AND "office" AND ("measurement" OR "metric" OR "KPI") -school -hospital chronic -rheumatology-virus\}; the inclusion terms were developed to ensure that the papers identified focused productivity measurement in the office context rather than the effect of underlying factors. After preliminary searches, the latter terms were added to eliminate the substantial number of studies used to address specific educational and healthcare contexts and effects of chronic diseases on workplace productivity, as these fall outside this review's scope. Next, screening criteria \{peer-reviewed, written in English, must relate specifically to workplace productivity measurement in the office context, focuses on KPIs rather than factors, includes empirical research or a comprehensive literature review, and is not specific to a particular disease or non-office context\} identified papers warranting full-text review. Each paper was independently reviewed by two of the authors to identify and classify KPIs, their methods of measurement, and contributing productivity enabling or hindering factors. Where discrepancies in evaluation arose, these were discussed and resolved with a third author. 


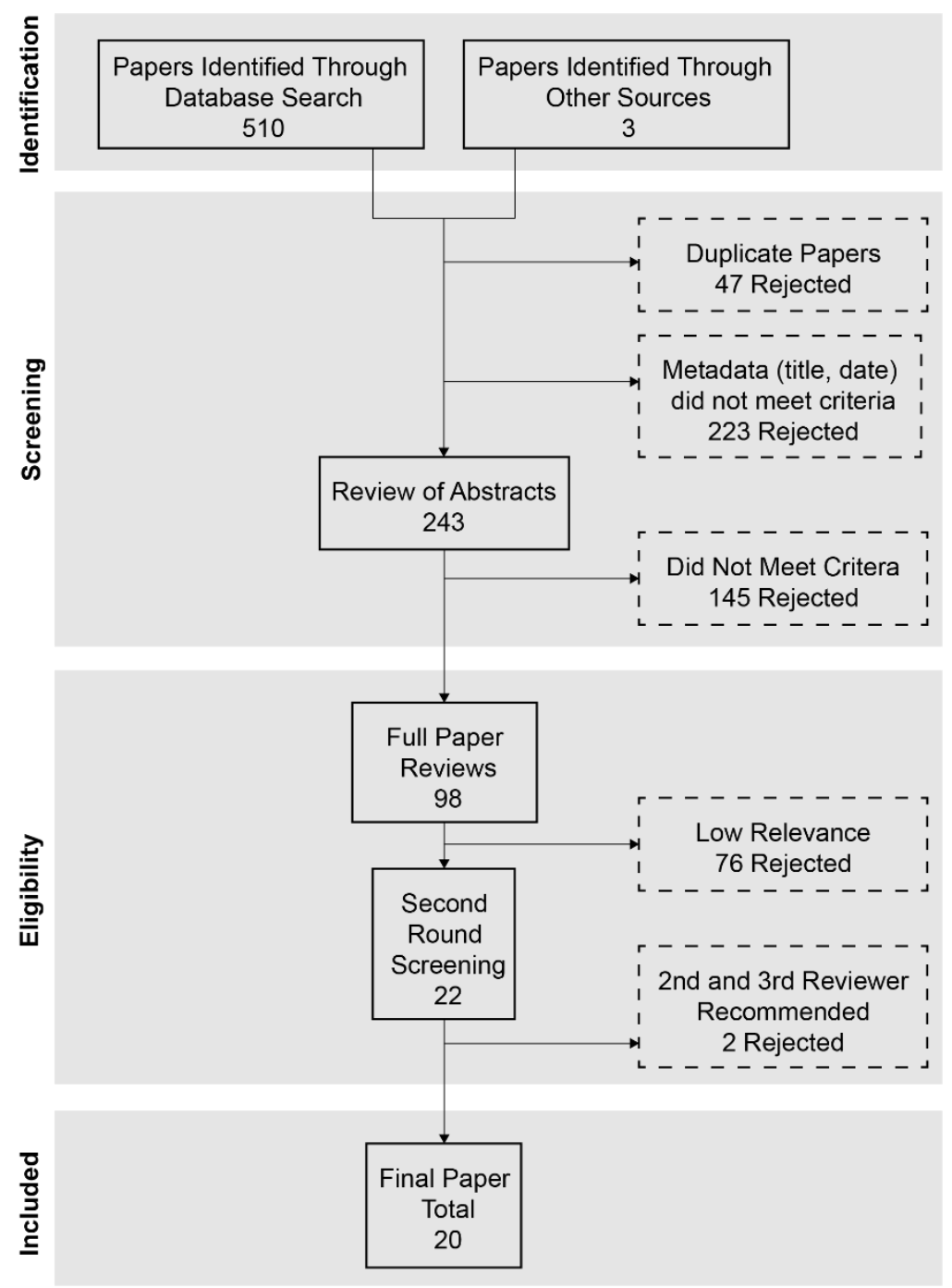

Figure 2 Literature Review Process

\subsection{Interview Methodology}

To inform the development of future productivity measurement tools, a series of semi-structured interviews with twelve experts across eight organizations - some providing consulting services for hundreds of client organizations - were conducted in parallel with the literature review. These interviews focused on the types of data recorded and maintained by organizations, with specific questions regarding the use of financial records to provide insight on workforce productivity, appraisals to assess individual worker performance, sources of absenteeism data, the use of worker engagement surveys, and the use of post-occupancy evaluations to measure contributing factors. Significant discussion in each interview focused on additional data, techniques, or insights that the expert felt were of realized or potential value in productivity 
measurement and trends in the adoption of such techniques. Interviews were recorded and transcript analysis identified key trends and novel insights that were used to contextualize the literature review findings and will support future tool development.

\section{Findings from Literature}

Of the 513 papers identified, 20 were selected for review. The reviewed papers were categorised by the type and location of each study, summarized in Table 1. Non-empirical studies (i.e., literature reviews and concept papers) are listed by author location(s). Note that papers containing multiple studies or hybridized methodologies are counted in all relevant categories and thus the total exceeds 20.

Table 1 Classification by types of empirical study and location (geometric region, type, etc.)

\begin{tabular}{|c|c|c|c|}
\hline Types of Study & Quantity & Location & Relevant Papers \\
\hline $\begin{array}{l}\text { Multi-site Survey/Questionnaire } \\
\text { (by mail/online) }\end{array}$ & 9 & $\begin{array}{l}\text { Australia } \\
\text { Japan (2) } \\
\text { Pakistan } \\
\text { Norway } \\
\text { United Kingdom (UK) (2) } \\
\text { UK + Netherlands } \\
\text { United States (USA) }\end{array}$ & $\begin{array}{l}\text { (Hosie \& Sevastos, 2009) } \\
\text { (Tanabe, et al., 2015) } \\
\text { (Shiba K., 2015) } \\
\text { (Saleem, et al., 2012) } \\
\text { (Wiik, 2011) } \\
\text { (Haynes, 2007) } \\
\text { (Haynes \& Price, 2004) (Nieuwenhuis, } \\
\text { et al., 2014) } \\
\text { (Gardner, et al., 2016) }\end{array}$ \\
\hline $\begin{array}{l}\text { Single Site Survey/Questionnaire } \\
\text { (by mail/online) }\end{array}$ & 5 & $\begin{array}{l}\text { Australia } \\
\text { Finland } \\
\text { New Zealand } \\
\text { UK } \\
\text { USA } \\
\text { Middle East }\end{array}$ & $\begin{array}{l}\text { (Purdey \& Leifer, 2012) } \\
\text { (Vänni K., 2012) } \\
\text { (Byrd \& Rasheed, 2016) } \\
\text { (Smith, et al., 2010) } \\
\text { (Boyce, et al., 2006) } \\
\text { (Haynes, et al., 2017) }\end{array}$ \\
\hline $\begin{array}{l}\text { Real Office Observation or } \\
\text { Measurement plus } \\
\text { surveys/questionnaires }\end{array}$ & 10 & $\begin{array}{l}\text { Australia (2) } \\
\text { Finland } \\
\text { Japan } \\
\text { Pakistan } \\
\text { UK (3) } \\
\text { UK + Netherlands } \\
\text { USA }\end{array}$ & $\begin{array}{l}\text { (Hosie \& Sevastos, 2009) } \\
\text { (Purdey \& Leifer, 2012) } \\
\text { (Vänni K., 2012) } \\
\text { (Shiba K., 2015) } \\
\text { (Saleem, et al., 2012) } \\
\text { (Haynes, 2007) } \\
\text { (Haynes \& Price, 2004) } \\
\text { (Smith, et al., 2010) } \\
\text { (Nieuwenhuis, et al., 2014) } \\
\text { (Gardner, et al., 2016) }\end{array}$ \\
\hline $\begin{array}{l}\text { Real Office Observation or } \\
\text { Measurement plus interviews }\end{array}$ & 2 & $\begin{array}{l}\text { New Zealand } \\
\text { Norway }\end{array}$ & $\begin{array}{l}\text { (Byrd \& Rasheed, 2016) } \\
\text { (Wiik, 2011) }\end{array}$ \\
\hline Lab or Simulated Office Study & 2 & $\begin{array}{l}\text { Japan } \\
\text { USA }\end{array}$ & $\begin{array}{l}\text { (Tanabe, et al., 2015) } \\
\text { (Boyce, et al., 2006) }\end{array}$ \\
\hline $\begin{array}{l}\text { Literature Review or Concept } \\
\text { Paper Discussing Existing Metrics } \\
\text { or summaries of previous studies }\end{array}$ & 5 & $\begin{array}{l}\text { UK (2) } \\
\text { USA (2) } \\
\text { USA + Helsinki }\end{array}$ & $\begin{array}{l}\text { (Haynes, 2007a) } \\
\text { (Haynes, 2008) } \\
\text { (Lack, 2011) } \\
\text { (Bosch-Sijtsema, et al., 2012) } \\
\text { (Howard, et al., 2006) }\end{array}$ \\
\hline
\end{tabular}


This demonstrates that self-assessment is the most common measurement tool for workplace productivity evaluation. Existing tools such as the Work Productivity and Activity Impairment Questionnaire (Gardner, et al., 2016; Lack, 2011; Howard, et al., 2006), are used to measure an individual's perceived performance to quantify the influence of various factors on productivity. While the subjective nature of self-assessment can bias results, it was the most widely-used evaluation technique, particularly regarding influences of factors on productivity.

The literature review identified a single instance where interviews were used to collect data for productivity measurement. The additional effort required to interview individual participants, the difficulty of recruiting a large number of participants for interviews, limiting sample size, and the time required for both interviews and the analysis of the unstructured data obtained are likely reasons for this limited adoption.

In many cases field studies in real office environments were undertaken to garner specific quantitative measurements of interest in response to physical changes in the office environment. In many cases, these field studies aimed to quantify the effects of specific factors - typically environmental - on the productivity of workers. In many cases the duration, sample size, and challenge of implementing a control condition limit the feasibility of conducting field studies. Nevertheless, these provide valuable information as they relate to actual job tasks rather than standardized tasks. In contrast, simulated office studies utilized standardized tasks and provide a more artificial environment. For specific task performance measurement, these have been demonstrated to provide valuable information on micro-scale productivity effects of specific factors (Boyce, et al., 2006).

\subsection{Key Performance Indicators}

Key Performance Indicators (KPIs) are classified based on their source type - either qualitative or quantitative and have been grouped as such in the tables in this section. In addition to this source type, each KPI listed includes information on the type of data (application area) as previously explained in the classificatory scheme, examples of specific metrics used as methods of measurement, as well as a reference to the study they were identified within.

The relationship between factors and KPIs was often difficult to qualify due to confounding categories used across the literature surveyed. While some studies presented in the reviewed 
literature were clear in the identification of KPIs as dependant variables and factors as independent sources (particularly when a statistical analysis was undertaken), others spoke primarily of items that the authors of this review define as factors, yet treated their measurement as an indicator of performance in its isolation.

\subsubsection{Quantitative}

Quantitative KPIs are defined as those whose underlying metrics use measured data from financial, organizational, or employees themselves, as presented in Table 2. Both primary (taskbased measurements and timesheets) and secondary (accounting records) populate the associated metrics.

Several thematic clusters of KPIs are noted in this data. A significant portion of these indicators relate to the time spent, wasted, or lost by individual employees for a variety of reasons. While absenteeism was the dominant metric, others related to lost time included health costs associated with longer-term absences and employee downtime during periods of transition, either related to physical environment or personnel changes (“churn costs”). Other metrics considered measurements of effective time, such as time worked (defined by billable hours and overtime reporting), financial outputs (\$/full time equivalent hour), and effectiveness in meeting scheduled targets. Of the time-related KPIs, absenteeism was most widely used with some consensus between studies. Howard et al. (2006) reviewed both the two dominant economic models used for absenteeism - the Human Capital Approach where lost wages are calculated, and Friction Costs to account for the reduced productivity associated temporarily replacing effective workers - and noted that these have also been applied with limitations to presenteeism. Smith et al. (2010) used the sickness absence records for the employees surveyed and calculated associated savings; while not explicitly stated, the Human Capital Approach appears to be the basis for these calculations. Both Lack (2011) and Howard et al. (2006) discuss absenteeism in a broader context alongside presenteeism, and note the use of several existing tools (HPQ (Kessler, et al., 2003), SPS (Koopman, et al., 2002), WPAI (Reilly, et al., 1993), EWPS (Endicott \& Nee, 1997)) to capture both absenteeism and presenteeism information from worker self-assessment. While providing a numeric score, these tools use qualitative inputs and are discussed in Section 3.1.2. 
Table 2 Quantitative KPIs

\begin{tabular}{|c|c|c|c|}
\hline KPI & Data Source(s) & Metric & References \\
\hline \multirow[t]{5}{*}{ Absenteeism } & \multirow[t]{2}{*}{ Financial } & Friction Cost & (Howard, et al., 2006) \\
\hline & & Human Capital & (Howard, et al., 2006) \\
\hline & Organizational & $\begin{array}{l}\text { Absence (\%) } \\
\text { Recorded Injuries } \\
\text { Annual Leaves }\end{array}$ & (Smith, et al., 2010) \\
\hline & \multirow[t]{2}{*}{ Worker Input } & Number of self-reported Absences & (Lack, 2011; Smith, et al., 2010) \\
\hline & & $\begin{array}{l}\text { Published surveys relating absence to } \\
\text { underlying health problems }\end{array}$ & $\begin{array}{l}\text { (Howard, et al., 2006; Lack, 2011; } \\
\text { Gardner, et al., 2016) }\end{array}$ \\
\hline \multirow{2}{*}{$\begin{array}{l}\text { Employee } \\
\text { turnover and } \\
\text { churn costs }\end{array}$} & \multirow{2}{*}{$\begin{array}{l}\text { Organizational + } \\
\text { Financial }\end{array}$} & Employee downtime, and move costs & (Haynes, 2007a) \\
\hline & & Cost to retain staff & (Haynes, 2007a) \\
\hline Health costs & $\begin{array}{l}\text { Organizational + } \\
\text { Financial }\end{array}$ & Lost value to sick leave, accidents, and injuries & (Haynes, 2007a) \\
\hline \multirow[t]{6}{*}{ Outputs } & \multirow[t]{2}{*}{ Financial } & $\%$ of established production goal reached & (Gardner, et al., 2016) \\
\hline & & Ratio of expected: used resources & (Haynes, 2007a) \\
\hline & \multirow[t]{4}{*}{ Financial } & \$/FTE Hr & (Lack, 2011) \\
\hline & & Goods or services completed/time & (Byrd \& Rasheed, 2016) \\
\hline & & Output: Input Ratio & (Bosch-Sijtsema, et al., 2012) \\
\hline & & Value of output/cost of input & (Haynes, 2007a) \\
\hline \multirow[t]{9}{*}{ Performance } & Financial & Meeting Set Targets & (Haynes, 2007a) \\
\hline & \multirow[t]{8}{*}{ Task Based } & Client Handling Time & (Nieuwenhuis, et al., 2014) \\
\hline & & Cognitive Judgement Testing & (Boyce, et al., 2006) \\
\hline & & Cognitive Performance Testing & (Boyce, et al., 2006) \\
\hline & & $\begin{array}{l}\text { Multiplication, proof reading and creative } \\
\text { thinking tasks }\end{array}$ & (Tanabe, et al., 2015) \\
\hline & & Time to complete and errors & (Haynes, 2007a) \\
\hline & & Timed Vision Test & (Boyce, et al., 2006) \\
\hline & & Typing Test & (Boyce, et al., 2006) \\
\hline & & Vigilance Test & (Boyce, et al., 2006) \\
\hline Profitability & Financial & Revenue: Operating Cost ratio & (Haynes, 2007a) \\
\hline \multirow[t]{2}{*}{ Time worked } & $\begin{array}{l}\text { Organizational + } \\
\text { Financial }\end{array}$ & Timesheets/Billable Hours & (Haynes, 2007a) \\
\hline & Organizational & Reported overtime hours & (Haynes, 2007a) \\
\hline
\end{tabular}

The evaluation of performance or output was extremely diverse, demonstrating the continued challenge of developing such a metric initially noted by Haynes (Haynes, 2007a). Quantified outputs consistently relied on financial data, with two studies considering performance relative to 
organizational expectations (Gardner, et al., 2016; Haynes, 2007a) and others considering only financial data (Bosch-Sijtsema, et al., 2012; Byrd \& Rasheed, 2016; Lack, 2011). The evaluation of performance at multiple scales - individual, team, and organization - was considered by several studies to provide a broader evaluation of productivity. Organizational or team metrics included the achievement of performance targets or goals as well as profitability, efficiency, or effectiveness, calculated using revenue: operating costs or expected: used resource ratios, providing objective measurements at this macroscopic level. Performance was measured both by the achievement of targets (Haynes, 2007a) and a variety of task-based approaches used by various researchers. Most such metrics were used in simulated office studies, while real office study metrics considered both quantity - the time to complete specific tasks - and quality as measured by the number of errors in completed work.

\subsubsection{Qualitative}

Qualitative KPIs are summarized in Table 3 and include four key KPIs: self-assessed performance, perceived work ability, presenteeism, and engagement. These measures rely entirely on worker input as a data source, either through a previously-published tool, or through a new tool prepared by the authors, in approximately equal measure. The published tools are primarily health impact-focused and discussed in detail by Despiégel et al. (2012).

Employee performance self-assessment, including both the assessment of one's own quality and quantity of work performed and how this had been affected by workplace factors was a KPI in $40 \%$ of all papers reviewed. Questions typically used seven point Likert scales and 1-10 scales, and synthesized into either an overall score or set of scores across multiple dimensions. In contrast to realized performance effects, the work ability KPI addresses the employee's perception of their capacity to complete their assigned work, specifically as affected by underlying health conditions rather than the outcomes. Of these latter studies, many had been cited in the literature as metrics for the calculation of presenteeism. This term, defined by Lack (2011) as "employees being present at work but unable to be fully engaged in the work environment” echoes the performance metric, and this duality - measuring performance as well as ability - demonstrates the diversity of perspectives on presenteeism in the literature. 
Table 3 Qualitative KPIs

\begin{tabular}{|c|c|c|c|}
\hline KPI & $\begin{array}{l}\text { Type(s) } \\
\text { of Data }\end{array}$ & Metric & Reference(s) \\
\hline \multirow{3}{*}{$\begin{array}{l}\text { Employee } \\
\text { performance self- } \\
\text { assessment }\end{array}$} & \multirow[t]{3}{*}{$\begin{array}{l}\text { Worker } \\
\text { Input }\end{array}$} & $\begin{array}{l}\text { Self-assessment and direct report's } \\
\text { assessment of supervisor }\end{array}$ & (Hosie \& Sevastos, 2009) \\
\hline & & $\begin{array}{l}\text { Perceived performance as affected by } \\
\text { enabling/hindering factors (Custom } \\
\text { survey) }\end{array}$ & $\begin{array}{l}\text { (Haynes \& Price, 2004 ; Haynes } \\
2007 \text {; Haynes 2008; Smith, et al., } \\
\text { 2010; Wiik, 2011; Saleem, et al., } \\
\text { 2012; Nieuwenhuis, et al., 2014; } \\
\text { Haynes et al., 2017) }\end{array}$ \\
\hline & & $\begin{array}{l}\text { Endicott Work Productivity Scale (EWPS) } \\
\text { (Endicott \& Nee, 1997) }\end{array}$ & Invalid source specified. \\
\hline \multirow[t]{7}{*}{$\begin{array}{l}\text { Perceived work } \\
\text { ability }\end{array}$} & \multirow[t]{7}{*}{$\begin{array}{l}\text { Worker } \\
\text { Input }\end{array}$} & $\begin{array}{l}\text { Health and Labor Questionnaire (HLQ) } \\
\text { (Roijen \& Essink-Bot, 2000) }\end{array}$ & (Howard, et al., 2006) \\
\hline & & $\begin{array}{l}\text { Work Productivity and Activity } \\
\text { Impairment Questionnaire (WPAI) (Reilly, } \\
\text { et al., 1993) }\end{array}$ & $\begin{array}{l}\text { (Howard, et al., 2006; Lack, 2011; } \\
\text { Gardner, et al., 2016) }\end{array}$ \\
\hline & & $\begin{array}{l}\text { Health and Work Performance } \\
\text { Questionnaire (HPQ) (Kessler, et al., } \\
\text { 2003) }\end{array}$ & $\begin{array}{l}\text { (Howard, et al., 2006; Lack, 2011; } \\
\text { Gardner, et al., 2016; Shiba K., } \\
\text { 2015) }\end{array}$ \\
\hline & & $\begin{array}{l}\text { The Work Limitations Questionnaire } \\
\text { (WLQ) (Lerner, et al., 2001) }\end{array}$ & $\begin{array}{l}\text { (Howard, et al., 2006; Lack, 2011; } \\
\text { Gardner, et al., 2016) }\end{array}$ \\
\hline & & $\begin{array}{l}\text { Work Ability Index (WAI) (Tuomi, et al., } \\
\text { 1998) }\end{array}$ & (Gardner, et al., 2016) \\
\hline & & Perceived Work-Ability Survey & (Vänni K., 2012) \\
\hline & & $\begin{array}{l}\text { Health and Work Questionnaire (HWQ) } \\
\text { (Shikiar, et al., 2004) }\end{array}$ & (Howard, et al., 2006) \\
\hline \multirow[t]{5}{*}{ Presenteeism } & \multirow[t]{5}{*}{$\begin{array}{l}\text { Worker } \\
\text { Input }\end{array}$} & $\begin{array}{l}\text { Stanford Presenteeism Scale } 6 \text { (SPS- } \\
\text { 6) (Koopman, et al., 2002) }\end{array}$ & (Lack, 2011) \\
\hline & & $\begin{array}{l}\text { Work Productivity and Activity } \\
\text { Impairment Questionnaire (WPAI) (Reilly, } \\
\text { et al., 1993) }\end{array}$ & (Lack, 2011; Gardner, et al., 2016) \\
\hline & & $\begin{array}{l}\text { Health and Work Performance } \\
\text { Questionnaire (HPQ) (Kessler, et al., } \\
\text { 2003) }\end{array}$ & (Lack, 2011; Gardner, et al., 2016) \\
\hline & & $\begin{array}{l}\text { The Work Limitation Questionnaire } \\
\text { (WLQ) (Lerner, et al., 2001) }\end{array}$ & (Lack, 2011; Gardner, et al., 2016) \\
\hline & & $\begin{array}{l}\text { Endicott Work Productivity Scale } \\
\text { (EWPS) (Endicott \& Nee, 1997) }\end{array}$ & (Lack, 2011) \\
\hline Engagement & $\begin{array}{l}\text { Worker } \\
\text { Input }\end{array}$ & $\begin{array}{l}\text { Utrecht Work Engagement Scale (UWES) } \\
\text { (Schaufeli \& Bakker, 2004) }\end{array}$ & (Shiba K., 2015) \\
\hline
\end{tabular}

The final qualitative KPI noted was engagement, measured using the UWES methods (Schaufeli \& Bakker, 2004) to determine worker dedication, absorption in work, and 'vigour' or ability to continue focused work. The widespread adoption of worker engagement surveys in industry 
suggests that while limited to a single paper reviewed, this KPI is valuable for tool development as existing data is often available to correlate or provide this metric.

\subsubsection{Mixed}

While most KPIs use either qualitative or quantitative metrics, only the Indoor Productivity Index (Wiik, 2011) uses both. This KPI uses worker input along with 225 questions rated using a 7-point Likert scale. While this metric uses a qualitative, subjective survey, as was the case with most of the worker-input KPIs explored, this KPI incorporates a method of analysis by which the results can be synthesized as a single quantitative metric. While to this point this is an approach unique to this study, it begins to present methods through which a holistic understanding can begin to emerge, and while preliminary attempts to synthesize data in a manner that is necessary to better understand the operations and productivity of a business or knowledge work environment.

\subsection{Contributing Factors}

Similar to the classification of KPIs the factors have also been extracted from the literature and characterized in one of three ways: (1) behavioral factors relating to personal attributes of employees, (2) organizational factors relating to policy and operating modes, or (3) physical factors relating to the working environment (i.e. building) and its defining characteristics.

\subsubsection{Personal}

Personal factors are defined as an employee's individual qualities and workplace behavioural attributes and are summarized in Table 4. These metrics are primarily identified through selfassessment due to their subjective nature. The literature speaks primarily to physical health, relating primarily to studies of absenteeism and presenteeism as performance measures, followed by psychological health and well-being.

From this review, it is clear that absenteeism and presenteeism are the dominant KPIs noted in the literature; while the former is largely agreed upon, the paper by Lack (2011) indicates a need to quantify presenteeism, and a lack of consensus on appropriate metrics to do so. The literature review outlines a variety of contributing factors which include: demographic information, distractions, fatigue, psychosocial factors, and most predominantly mental and physical health. 
Table 4 Behavioral factors

\begin{tabular}{|c|c|c|c|}
\hline Factor & Sub-factors & Measurement(s) used & References \\
\hline Demographics & $\begin{array}{l}\text { Gender, age, working area, } \\
\text { smoking habits, periods of } \\
\text { affiliation in the current company, } \\
\text { and education level }\end{array}$ & $\begin{array}{l}225 \text { statements rated on seven- } \\
\text { point Likert scale based on } \\
\text { guidelines (Morrel-Samuels, 2002) } \\
\text { Survey on perceived performance } \\
\text { impact of factors, results evaluated } \\
\text { by age and gender groupings }\end{array}$ & $\begin{array}{l}\text { (Haynes, et al., } \\
\text { 2017) }\end{array}$ \\
\hline Distraction & $\begin{array}{l}\text { Interruptions, crowding, noise, } \\
\text { privacy, overall atmosphere }\end{array}$ & $\begin{array}{l}\text { Employee Questionnaire (Non- } \\
\text { Standardized) }\end{array}$ & $\begin{array}{l}\text { (Haynes, 2007); } \\
\text { (Haynes, et al., } \\
\text { 2017) (Purdey } \\
\text { \& Leifer, 2012) }\end{array}$ \\
\hline \multirow[t]{8}{*}{ Physical Health } & Physical symptoms & $\begin{array}{l}\text { Patient Health Questionnaire (PHQ- } \\
\text { 15) (Kroenke, et al., 2003) }\end{array}$ & $\begin{array}{l}\text { (Gardner, et al., } \\
\text { 2016) }\end{array}$ \\
\hline & $\begin{array}{l}\text { Work ability, illnesses, diseases, } \\
\text { limiting conditions, sick leave }\end{array}$ & $\begin{array}{l}\text { Work Ability Index (WAI) (Tuomi, et } \\
\text { al., 1998) }\end{array}$ & $\begin{array}{l}\text { (Gardner, et al., } \\
\text { 2016) }\end{array}$ \\
\hline & $\begin{array}{l}\text { Time management, physical } \\
\text { demands, mental/interpersonal, } \\
\text { and output demands }\end{array}$ & $\begin{array}{l}\text { Work Limitation Questionnaire } \\
\text { (WLQ) (Lerner, et al., 2001) }\end{array}$ & $\begin{array}{l}\text { (Gardner, et al., } \\
\text { 2016); (Lack, } \\
\text { 2011) }\end{array}$ \\
\hline & $\begin{array}{l}\text { Illness/disease/chronic conditions, } \\
\text { smoking, drinking, mental } \\
\text { wellbeing, } \\
\text { attention/concentration, energy } \\
\text { levels/sleep, sick days }\end{array}$ & $\begin{array}{l}\text { Health and Work Performance } \\
\text { Questionnaire (HPQ) (Kessler, et al., } \\
\text { 2003) }\end{array}$ & $\begin{array}{l}\text { (Gardner, et al., } \\
\text { 2016); (Lack, } \\
\text { 2011) }\end{array}$ \\
\hline & $\begin{array}{l}\text { Health limitations on work, } \\
\text { hours/days absent }\end{array}$ & $\begin{array}{l}\text { Work Productivity and Activity } \\
\text { Impairment Questionnaire (WPAI) } \\
\text { (Reilly, et al., 1993) }\end{array}$ & $\begin{array}{l}\text { (Gardner, et al., } \\
\text { 2016); (Lack, } \\
\text { 2011) }\end{array}$ \\
\hline & Self-assessed health & $\begin{array}{l}\text { Employee Questionnaire (Non- } \\
\text { Standardized) }\end{array}$ & (Vänni K., 2012) \\
\hline & Self-assessed health & $\begin{array}{l}\text { Stanford Presenteeism Scale (SPS-6) } \\
\text { (Koopman, et al., 2002) }\end{array}$ & (Lack, 2011) \\
\hline & $\begin{array}{l}\text { Attitudes, behaviours, and } \\
\text { disorders }\end{array}$ & $\begin{array}{l}\text { Endicott Work Productivity Scale } \\
\text { (EWPS) (Endicott \& Nee, 1997) }\end{array}$ & (Lack, 2011) \\
\hline \multirow[t]{2}{*}{ Mental Health } & $\begin{array}{l}\text { Mental health impacts on work } \\
\text { ability }\end{array}$ & WPAI, WLQ, HPQ, SPS-6, EWPS & (Lack, 2011) \\
\hline & Job-related stress & $\begin{array}{l}\text { BJSQ (Brief Job Stress } \\
\text { Questionnaire) (Shimomitsu, 1998) }\end{array}$ & (Shiba K., 2015) \\
\hline Fatigue & Mental fatigue, subjective fatigue & $\begin{array}{l}\text { Occupational Fatigue Approach } \\
\text { (Yoshitake, 1973) }\end{array}$ & $\begin{array}{l}\text { (Tanabe, et al., } \\
\text { 2015) }\end{array}$ \\
\hline Psychosocial & $\begin{array}{l}\text { Leadership, goal-setting } \\
\text { cooperation, loyalty, control, } \\
\text { perceived performance }\end{array}$ & $\begin{array}{l}225 \text { statements rated on seven- } \\
\text { point Likert scale }\end{array}$ & (Wiik, 2011) \\
\hline
\end{tabular}

These physical and mental health factors, particularly as measured through employee questionnaires, were the most widely disseminated. In most cases these measurements are undertaken through questionnaires relating health and productivity or presenteeism. In Lack (2011) several established questionnaires were evaluated on a number of criteria including construct validity and reliability and were found to be either established and high or to have 
insufficient information to evaluate. In contrast, Gardiner et al. (2016) found a weak to moderate correlation between questionnaires and employer metrics; however, this was partially attributed to limited sample size, and the ongoing discussion on self-assessed bias is discussed further towards the end of this paper. Both Wiik (2011) and Haynes et al. (2017) also noted influence of specific demographics (age, gender) on both productivity and the strength of effect of other factors.

\subsubsection{Organizational Factors}

Organizational factors are characterized as the operational structure of a workplace and these predominantly focused on managerial interactions and operations in the literature surveyed. While less broadly considered than environmental and personal factors; organizational factors were the main focus of the research of Bosch-Sijtsema, et al. (2012). This work considered three subsets of factors within the organizational domain: time spent in different modes of working, team processes, and team structure. Time spent in different modes of working assessed the organization's modes of operation by types of interaction, time alone, and the use of technology to facilitate interaction. The former issues had previously been investigated by Haynes (Haynes, 2007a) while the latter of these has become a popular research topic, including a follow-up paper to the 2012 study by Bosch-Sijtsema \& Henriksson (2014). The evaluation of team processes considered the planning, execution or action of tasks and other processes related to team structure. Finally, team structure included a consideration team size, diversity of roles and skillsets and knowledge-base. Bosch-Sijtsema et al. (2012) noted a difficulty in developing metrics to translate these factors to KPIs. This difficulty may have contributed to the paucity of research noted on this topic. Other than the Perceived Productivity Impact metric proposed by Haynes et al. (2017), focused more on physical layout of offices but also considering team and organization dynamics, there have been few metrics to attempt to quantify the effect of soft organizational factors. Some organizational factors, for example modes of operation, are challenging to relate to productivity and performance; conversely, factors such as market demands and the frequency of interruptions are more readily quantified. Market demands are discussed in Haynes (2007a) and can directly impact effectiveness, efficiency, outputs and performance due to the external requirements imposed for the completion of specific tasks. Similarly, interruptions can affect an individual's time on task, measured through billable hours 
and task completion (Wiik, 2011); these are discussed in detail in the context of open-plan office studies such as that by Purdey and Leifer (2012).

\subsubsection{Building Environment Factors}

Building environment factors consider both the visible office features and indoor environmental conditions, for example temperature, humidity, air quality, noise, and lighting. Table 5 summarizes these factors, which were measured through both quantitative environmental measurements, and worker comfort or impact assessment. This duality of measurement allows both the absolute value to be assessed (for condition benchmarking) as well as the perceived impact of the environment on productivity through questionnaires, which in turn rely on relative (e.g. “too warm”) rather than absolute (e.g. $28^{\circ} \mathrm{C}$ ) descriptors.

Statistically significant differences in the strength of all types of factors were noted between groups occupying individual, shared, and open-plan offices in a recent study by Haynes et al. (2017). While limited to a single region, this echoes findings from the broader literature, particularly those relating distraction (negative) and collaboration (positive) to the open-plan office layout (Haynes \& Price, 2004; Haynes, 2007; Purdey \& Leifer, 2012). While Haynes et al. (2017) describes the unilateral impacts of the workplace layout across both open-plan and enclosed office environments, they note that it is the availability and the control over a variety of physical layouts and social interaction points which has the greatest impact on perceived workability. In order to determine these impacts, Haynes (2007a) identifies the trend in the traditional evaluation of workplace productivity to rely on self-assessment as the primary means of evaluating the impact of factors. As seen in Table 5, the majority of factors identified rely on a questionnaire or some other means of self-assessment in their measurement. The remaining factors focus specifically on empirical building environmental factors, such as relative humidity, temperature, and light levels; however, all of these were further supplemented with questionnaires to evaluate their impact employees. 
Table 5 Building Environment factors

\begin{tabular}{|c|c|c|}
\hline Factor & Means of Data Collection & References \\
\hline \multirow[t]{2}{*}{ Air Quality } & $\begin{array}{l}\text { Questionnaire identifying relative importance of air } \\
\text { quality }\end{array}$ & (Byrd \& Rasheed, 2016) \\
\hline & Questionnaire identifying perception of air quality & (Wiik, 2011) \\
\hline $\begin{array}{l}\text { Air } \\
\text { Temperature }\end{array}$ & $\begin{array}{l}\text { 10-minute interval physical measurements + monthly } \\
\text { self-assessments of environmental comfort }\end{array}$ & (Tanabe, et al., 2015) \\
\hline \multirow[t]{2}{*}{ Cleanliness } & Questionnaire & (Haynes, 2007) \\
\hline & Questionnaire & (Haynes \& Price, 2004) \\
\hline $\mathrm{CO}_{2}$ Levels & Physical Testing & (Wiik, 2011) \\
\hline \multirow[t]{2}{*}{ Comfort } & Questionnaire & $\begin{array}{l}\text { (Haynes, 2007) } \\
\text { (Haynes, et al., 2017) }\end{array}$ \\
\hline & Questionnaire & (Haynes \& Price, 2004) \\
\hline \multirow[t]{2}{*}{ Décor } & Questionnaire & (Haynes, 2007) \\
\hline & Questionnaire & (Haynes \& Price, 2004) \\
\hline $\begin{array}{l}\text { Degree of } \\
\text { Openness }\end{array}$ & Questionnaire & $\begin{array}{l}\text { (Haynes \& Price, 2004) (Haynes, et } \\
\text { al., 2017) (Purdey \& Leifer, 2012) }\end{array}$ \\
\hline \multirow[t]{2}{*}{$\begin{array}{l}\text { Formal } \\
\text { Meeting Areas }\end{array}$} & Questionnaire & $\begin{array}{l}\text { (Haynes, 2007) } \\
\text { (Haynes, et al., 2017) }\end{array}$ \\
\hline & Questionnaire & (Haynes \& Price, 2004) \\
\hline \multirow{2}{*}{$\begin{array}{l}\text { Furniture } \\
\text { (Ergonomics) }\end{array}$} & Impact Self-Assessment & (Saleem, et al., 2012) \\
\hline & Questionnaire & (Wiik, 2011) \\
\hline \multirow[t]{2}{*}{$\begin{array}{l}\text { Informal } \\
\text { Interaction }\end{array}$} & Questionnaire & $\begin{array}{l}\text { (Haynes, 2007) } \\
\text { (Haynes, et al., 2017) }\end{array}$ \\
\hline & Questionnaire & (Haynes \& Price, 2004) \\
\hline \multirow[t]{2}{*}{$\begin{array}{l}\text { Informal } \\
\text { Meeting Areas }\end{array}$} & Questionnaire & $\begin{array}{l}\text { (Haynes, 2007) } \\
\text { (Haynes, et al., 2017) }\end{array}$ \\
\hline & Questionnaire & (Haynes \& Price, 2004) \\
\hline \multirow[t]{2}{*}{ Interaction } & Questionnaire & $\begin{array}{l}\text { (Haynes, 2007) } \\
\text { (Haynes, et al., 2017) }\end{array}$ \\
\hline & Questionnaire & (Haynes \& Price, 2004) \\
\hline \multirow[t]{4}{*}{$\begin{array}{l}\text { Lighting (Level } \\
\text { and quality) }\end{array}$} & $\begin{array}{l}\text { Physical (illuminance) measurements; questionnaires } \\
\text { (both impact self-assessment and response to } \\
\text { environmental conditions) }\end{array}$ & (Boyce, et al., 2006) \\
\hline & Impact Self-Assessment & (Saleem, et al., 2012) \\
\hline & \multirow[t]{2}{*}{ Questionnaire } & (Wiik, 2011) \\
\hline & & (Haynes \& Price, 2004) \\
\hline \multirow[t]{3}{*}{ Noise } & Impact Self-Assessment & $\begin{array}{l}\text { (Saleem, et al., 2012) (Haynes, et } \\
\text { al., 2017) }\end{array}$ \\
\hline & \multirow[t]{2}{*}{ Questionnaire } & (Wiik, 2011) \\
\hline & & (Wiik, 2011) \\
\hline \multirow[t]{2}{*}{ Office Layout } & Narrative literature review & (Haynes, 2008) \\
\hline & Questionnaire & $\begin{array}{l}\text { (Haynes \& Price, 2004) (Haynes, } \\
\text { 2007) } \\
\text { (Haynes, et al., 2017) } \\
\text { (Purdey \& Leifer, 2012) }\end{array}$ \\
\hline
\end{tabular}




\begin{tabular}{|c|c|c|}
\hline \multirow[t]{2}{*}{ Plant Life } & $\begin{array}{l}\text { Number of plants in control versus test group (surveys, } \\
\text { handling time, time to complete task) }\end{array}$ & (Nieuwenhuis, et al., 2014) \\
\hline & $\begin{array}{l}\text { Self-assessment survey before and after integration of } \\
\text { plants. Physical measurement of; number, type vitality } \\
\text { and visibility of plants }\end{array}$ & (Smith, et al., 2010) \\
\hline \multirow[t]{2}{*}{$\begin{array}{l}\text { Relative } \\
\text { Humidity }\end{array}$} & $\begin{array}{l}10 \text { minute interval measurements - combined with } \\
\text { monthly self-assessments of environmental comfort }\end{array}$ & (Tanabe, et al., 2015) \\
\hline & Physical Testing & (Wiik, 2011) \\
\hline $\begin{array}{l}\text { Supply Air } \\
\text { Temperature, } \\
\text { Vertical Air } \\
\text { Temperature } \\
\text { Profile }\end{array}$ & $\begin{array}{l}10 \text { minute interval measurements - combined with } \\
\text { monthly self-assessments of environmental comfort }\end{array}$ & (Tanabe, et al., 2015) \\
\hline \multirow[t]{3}{*}{ Temperature } & Impact Self-Assessment & (Saleem, et al., 2012) \\
\hline & Physical Testing & (Wiik, 2011) \\
\hline & Questionnaire & (Haynes \& Price, 2004) \\
\hline \multirow[t]{2}{*}{$\begin{array}{l}\text { Thermal } \\
\text { Comfort }\end{array}$} & $\begin{array}{l}\text { Questionnaire identifying relative importance of } \\
\text { thermal comfort }\end{array}$ & (Byrd \& Rasheed, 2016) \\
\hline & Questionnaire & (Wiik, 2011) \\
\hline Ventilation & Questionnaire & (Haynes \& Price, 2004) \\
\hline Views & $\begin{array}{l}\text { Questionnaire identifying relative importance of access } \\
\text { to views }\end{array}$ & (Byrd \& Rasheed, 2016) \\
\hline $\begin{array}{l}\text { Visual } \\
\text { Disturbance }\end{array}$ & Questionnaire & (Wiik, 2011) \\
\hline
\end{tabular}

\subsection{Factors versus Indicators}

As has been previously noted, there is a lack of clarity in the literature when it comes to differentiating Key Performance Indicators from their confounding factors. While in certain cases there may be a fine line in defining when a factor becomes an indicator, more care is required in identifying this moving forward. In many cases the confusion arises around items that are task or activity related. For example, Nieuwenhuis et al. (2014) and Purdey and Leifer (2012) identify concentration in their research - a factor that correlates with the distractibility KPI. In many cases, the easiest method of discerning the two is to treat independent variables as factors and dependent outcomes are KPIs. Key Performance indicators, are then the means by which a quantifiable variance in productivity can be measured.

\section{Contextualizing the Results}

The literature review was supplemented by semi-structured interviews with workplace productivity specialists and office management experts to provide insight on current industry practice regarding workplace productivity measurement. The interviewees were asked a series of 
questions related to 5 main areas of interest: (1) absenteeism tracking within the organization, (2) financial performance metrics and their maintenance, (3) employee, team, manager performance appraisals, (4) office post-occupancy evaluations, and (5) employee engagement/satisfaction surveys. This discussion section references the trends identified in the data and identifies corroborations or contrasts within this expert insight, providing a link between the academic research and real-world context. Absenteeism was one area where almost all industries represented were in consensus, with absences tracked, to varying level of detail, most commonly on weekly timesheets in $86 \%$ of respondents. Similarly, employee appraisals were conducted by all and used annual targets, and semi-annual, or annual evaluation. Employee satisfaction and/or engagement surveys (or some similar evaluative tool) were also common (specifically noted by 43\% but alluded to an additional 22\%), though the actual tool utilized and what they measured varied widely from spatial, to organisational satisfaction and behavioural factors.

For financial data, the interviewees identified 12 different metrics used by their organizations (or organization's clients) to track financial performance: cost $/ \mathrm{ft}^{2}$, cost/employee, real estate value, overhead, volume / employee, ratio of pay to sales, sales targets, turnover, timesheets, annual spending, training budget, and project based spending. While some of these were identified by only one organization, 57\% noted that most of their financials were tracked and reported by project. This tracking includes employee timesheets and billable hour reporting to specific tasks. Other interviewees reported metrics largely based on the divergent fields of practice.

The least commonly-adopted measurement tool was the post-occupancy evaluation, with only one organization stating they were rolling them out in some offices, though it is important to note that a number of the organizations were currently going through moves at the time of interview and stated their intent to undertake such an evaluation in the new space.

\subsection{Issues Surrounding Self-Assessment}

Based upon the results of the literature review, it is apparent that significant research relies on employee self-assessment surveys and questionnaires. Of the 19 papers reviewed in the final stage of the structured literature review, 13 utilised some form of employee survey or questionnaire (often quantified through the use of a Likert scale) to measure at least one, but often multiple KPIs. This aligns with the current practice in knowledge-worker industries where companies interviewed to date report the use of scheduled employee engagement surveys, and 
semi-live or rolling pulse surveys to monitor multiple sets of information about their company. This practice functions in place of a comprehensive productivity metric due to their belief that relying on self-assessment is better than having no metrics at all (Haynes, 2007a). Other studies question the value of these measurements in trying to evaluate the real status of productivity in the office. Gardner et al. (2016) tested the effectiveness of these tools against empirical financial and organizational data from companies to gauge the accuracy of self-reported results. Results of this latter study suggested poor correlation between this empirical and self-assessed data, but the sample size was too small to be conclusive; more research is necessary to determine the true value (or lack thereof) of such assessments. Lee et al (2002) determined a variance in responses based on the culture of participants when completing Likert-type scale surveys (Lee, et al., 2002) and the need to use Cronbach's alpha to gauge internal consistency is highlighted in another study (Gliem \& Gliem, 2003). This challenge of attempting to quantify a qualitative or subjective assessment remains within contemporary literature but the broad consensus is that this assessment is of unique value in worker productivity measurement, particularly when the impact of a factor on productivity is of interest.

Two experts interviewed echoed the insight from the literature. The CEO of a corporate interior design firm discussed the challenge of trying to get specific answers from non-specific questions on conventional questionnaires. Similarly, the President of a workplace solution company discussed their frustration with standardized questionnaires, deciding to develop their own employee engagement survey in house.

\subsection{Availability of Data for Workplace Productivity Measurement}

Each company interviewed maintained their own records of possible productivity indicators. These datasets varied greatly from company to company and more so from industry to industry due to differences in industry standards, variations in company policy, and contract structures of employees, but employee absenteeism and appraisal data were consistently collected. Financial information was also consistently collected, however the breadth of reported metrics indicates the need for tailoring of this metric to each organization. The CEO from a corporate interior design firm lamented the lack of non-financial metrics to accurately measure productivity. This was a result of the lack of administrative personnel available to maintain such records. A VP of a corporate real estate and facilities management firm identified their company's desire to establish 
a quantifiable means of connecting the space designed to an individual's preferences and their subsequent performance.

In the academic literature, the low usage of company financial, organizational, or any other metrics may be due to this perceived non-uniformity. This lack of a universal metric is the reason many companies turn to using subjective assessments, or no assessment at all (Gardner, et al., 2016).Similarly, when interviewees were asked what other metrics are tracked that may affect or measure productivity, 36 unique responses were given covering the full breadth of metrics noted in the literature review. This establishes the need to synthesize Key Performance Indicators to provide companies the means of determining their productivity performance. This need was echoed interviewees from a public-sector organisation who noted the abundance of data and information that is tracked and its limited use: "We track a lot more than I thought we did, we just don't do much with it."

\subsection{Workplace 2.0 and beyond}

Information gathered from both the literature review and in person expert interviews both shed light on some of the impacts of generational and ideological changes in the workplace. Three types of changes have resulted: (1) Organisational Structures, (2) Physical Working Environments, and (3) Employer-Employee Relations. The first refers to the reduction of workplace hierarchy; one such example is Holocracy, a self-organisational system which brings structure and discipline to a peer-to-peer workplace (Roelofsen \& Yue, 2017). Further examples include manager-less organizations and the lattice organization, a de-stratified organisational structure (Benko \& Anderson, 2011).

Physical work environment changes began with open-plan office layouts starting in the 1960s (Oldham \& Brass, 1979), the dominance of cubicles by the end of the 1990s (Mamuji, et al., 2004) and "hoteling" in the mid-2000s, enabled by mobile technology. A Financial Institution Change Lead noted that their offices are being restructured to accommodate work experiences rather than specific individuals. Interviewees from both the public and private sectors indicated interest in quantifying the productivity impacts of such changes in their offices.

The generational shift has reduced workplace formality (Akitomi, et al., 2011) and employee empowerment through flexible and dynamic workspaces (Lang \& Preece, 2016). Companies are 
responding to younger employees’ demands for flexible work schedules, informal and increasingly frequent appraisals, and more self-directed work within prescribed deadlines. One interviewee described their firm's new assessment strategy: an employee engagement survey, annual performance review, employee advisory board, and regular performance check-ins with supervisors. Combining this with increased remote working and hoteling, managers have shifted from day-to-day supervision towards active coaching and support. One interviewee noted a shift to short, regular surveys to develop a snapshot of employee engagement but indicated - along with the majority of interviewees - the desire for a repeatable, auditable, and comprehensive standard means to evaluate workplace productivity.

\section{Conclusions and Implications for Workplace Productivity Measurement}

Since the review completed by Haynes (2007a), there has been a diversity of research in workplace productivity within the office context. The 20 papers reviewed have indicated a series of dominant workplace productivity KPIs and metrics. While significant future research is required to develop and test a multidimensional tool capturing these aspects, the literature review and insight from expert interviews has informed a theoretical framework for office worker productivity.

Several of Haynes conclusions from 2007 remain unchallenged by this recent literature. First, the complexity of the office and its inherent social context lead to lack of clear definition of workplace productivity; this continues to be demonstrated in both the literature, which demonstrates a breadth of potential KPIs, the difficulty expressed by interviewees to define productivity. This comprehensive metric continues to be the "holy grail" of this field. Second, while not universally accepted, "it is clear that the self-assessed measure of productivity is better than no measure of productivity" (Haynes, 2007a, p. 153). The shift towards self-assessed productivity - and more notably, the self-assessed impact of confounding factors - has been well-established, with several other researchers (Saleem, et al., 2012; Nieuwenhuis, et al., 2014; Smith, et al., 2010; Wiik, 2011) incorporating this self-assessment as a primary means of measuring productivity.

Finally, Haynes noted that the lack of validated theoretical framework has led to lack of consensus and wide range of methods used across the discipline. The broader research supported by this research aims to address this through the framework proposed in Figure 3. Four KPIs 
selected for inclusion in this framework. Absenteeism, represents the extreme case of unproductive time and captures the time lost due to unplanned absences such as illness or disability leave. In this framework, vacation allowance is excluded in recognition that this time is necessary for maintaining good mental health. The three remaining KPIs quantify different aspects of at-work performance. Engagement, using tools similar to UWES-9 (Schaufeli \& Bakker, 2004) and available corporate surveys, evaluates both morale and broader employee dedication levels. Two KPIs provide a holistic perspective on performance from the individual to overall organization scale. Output and performance metrics relating organization or team performance to company goals provide an objective measure of the overall productivity, and is complemented by self-assessed productivity to allow quantify the effect of specific factors on worker performance. This latter metric considers perceived work ability and performance and how these have been impacted by each type of factor, and thus is used to represent presenteeism.

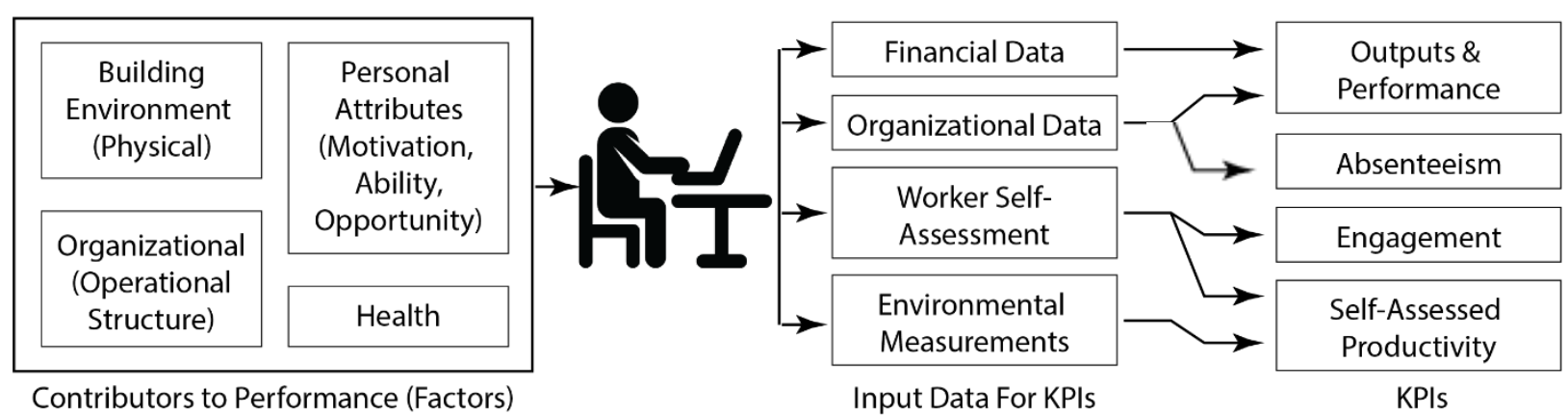

Figure 3 Theoretical framework for office worker productivity measurement

There is significant industry interest to improve worker productivity and engagement through changes in the workplace environment. The impact of air quality on productivity has become a frequent topic of discussion in business periodicals (Allen, 2017), as has the incorporation of biophilic elements in workspaces (HR News, 2017; Harvard Business review, 2017). There is a strong desire to establish links between real estate and FM performance metrics and organizational performance metrics, and this review has aimed to synthesize the state of office worker productivity research to support this goal.

To better inform future workplace decisions in the context of the evolution of office design, employers are increasingly seeking appropriate workplace productivity metrics. Expert interviews echoed the literature findings that self-assessment questionnaires - a topic of some controversy in the literature - are heavily relied upon due to the lack of consensus of a singular 
KPI to define office worker productivity. The interviewee responses presented herein will be important in the development of a workplace productivity benchmarking tool, not only through the identified similar metrics, but also through the nuanced difference. In places where companies are tracking similar types of information, through slightly different metrics for example, target-based measurement can be adopted, as is done with budgets and employee appraisals. This review aimed to identify this single KPI and rather found instead that there is significant consensus on the validity of a multitude of KPIs to evaluate aspects of knowledge worker productivity. Future research is needed to build upon the framework presented to develop and test a multi-dimensional benchmarking tool synthesizing these KPIs to provide holistic insight on office worker productivity.

\section{References}

(Papers selected for systematic review are indicated with *)

Akitomi, T., Ara, K., Watanabe, J.-i. \& Yano, K., 2011. Generic Model of Activity-Level in Workplace Communication. Boston, IEEE.

Allen, J. G., 2017. Research: Stale office air is making you less productive. Harvard Business Review, 21 March.

Avery, C. \& Zabel, D., 2001. The Flexible Workplace: A Sourcebook of Information and Research. London: Quorum Books.

Benko, C. \& Anderson, M., 2011. The Lattice That Has Replaced The Corporate Ladder. Forbes, 16 March.

*Bosch-Sijtsema, P. M., Ruohomaki, V. \& Vartiainen, M., 2012. Knowledge work productivity in distributed teams. Journal of Knowledge Management, 10(2), pp. 102-113.

*Boyce, P. R. et al., 2006. Lighting quality and office work: two field simulation experiments. Lighting Research and Technology, 38(3), pp. 191-223.

Brynjolfsson, E., 1993. The productivity paradox of information technology. Communivations of the ACM, 36(12), pp. 66-77.

*Byrd H. \& Rasheed. E.O, 2016. The productivity paradox in green buildings. Sustainability, 8(4), pp. 347-360. 
Choi, J.-H., Beltran, L. O. \& Kim, H.-S., 2012. Impacts of indoor daylight environments on patient average length of stay (ALOS) in a healthcare facility.. Building and Environment, Volume 50, pp. 65-75.

Cole, R., Oliver, A. \& Blaviesciunaite, A., 2014. The changing nature of workplace culture. Facilities, 32(13/14), pp. 786-800.

Dravigne, A., Waliczek, T. M., Lineberger, R. \& Zajicek, J., 2008. The effect of live plants and window views of green spaces on employee perceptions of job satisfaction. HortScience, 43(1), pp. 183-187.

Endicott, J. \& Nee, J., 1997. Endicott work productivity scale (EWPS): A new measure to assess treatment effects. Psychopharmacology Bulletin, 31(1), p. 13.

Feige, A., Wallbaum, H., Janser, M. \& Windlinger, L., 2013. Impact of sustainable office buildings on occupant's comfort and productivity. Journal of Corporate Real Estate, 15(1), pp. 7-34.

*Gardner, B. et al., 2016. Comparison of employer productivity metrics to lost productivity estimated by commonly used questionnaires. Journal of Occupational and Environmental Medicine, 58(2), pp. 170-177.

Gliem, J. \& Gliem, R., 2003. Calculating, interpreting, and reporting Cronbach's alpha reliability for Likert-type scales, Columbus: Midwest Research to Practice Conference. Guo, L., Wong-On-Wing, B. \& Lui, G., 2014. Input-based performance evaluation, incentive intensity, and proactive work behavior.. Advances in Management Accounting, pp. 185-223. Harvard Business review, 2017. Why You Should Tell Your Team to Take a Break and Go Outside. [Online]

Available at: https://hbr.org/2017/06/why-you-should-tell-your-team-to-take-a-break-and-gooutside

[Accessed 2407 2017].

*Haynes, B., Suckley, L. \& Nunnington, N., 2017. Workplace productivity and office type: An evaluation of office occupier differences based on age and gender. Journal of Corporate Real Estate, 19(2), pp. 111-138.

*Haynes, B. P., 2007. Office productivity: a theoretical framework. Journal of Corporate Real Estate, 9(2), pp. 97-110. 
*Haynes, B. P., 2007a. An evaluation of office productivity measurement. Journal of Corporate Real Estate, 9(3), pp. 144-156.

*Haynes, B. P., 2008. The impact of office layout on productivity. The Journal of Facilities Management, 6(3), pp. 189-201.

*Haynes, B. \& Price, I., 2004. Quantifying the complex adaptive workplace. Facilities, 22(1), pp. 8-18.

Heschong, L., 1999. Daylighting in schools: an investigation into the relationship between daylighting and human performance. [Online]

Available at: http://eric.ed.gov/?id=ED444337

[Accessed 4 September 2015].

*Hosie, P. J. \& Sevastos, P., 2009. Does the "happy-productive worker” thesis apply to managers?. International Journal of Workplace Health Management, 2(2), pp. 131-160.

*Howard, K. J., Howard, J. T. \& Alessa, M. S. F., 2006. The Problem of Absenteeism and Presenteeism in the Workplace. Handbook of occupational health and wellness, 38(3), pp. 191223.

HR News, 2017. 5 Science-Backed Improvements to Propel Productivity in Your Office. [Online] Available at: http://hrnews.co.uk/5-science-backed-improvements-propel-productivity-office/ [Accessed 2407 2017].

Juslén, H. T., Wouters, M. C. H. M. \& Tenner, A. D., 2007. Lighting level and productivity: a field study in the electronics industry.. Ergonomics, 50(4), pp. 615-624.

Kessler, R. et al., 2003. The World Health Organization Health and Work Performance Questionnaire (HPQ). Journal of Occupational \& Environmental Medicine, 45(2), pp. 156-174. Koopman, C. et al., 2002. Stanford presenteeism scale: health status and employee productivity. Journal of Occupational \& Environmental Medicine, 44(1), pp. 14-20.

Kroenke, K., Spitzer, R. \& Williams, J., 2003. The patient health questionnaire-2: Validity of a two-item depression screener. Medical Care, 41(11), pp. 1284-1292.

*Lack, D. M., 2011. Presenteeism Revisited. AAOHN Journal, 59(2), pp. 77-89.

Lang, S. \& Preece, S., 2016. What Workers Want, London: British Council for Offices. Larsen, L., JefferyAdams, Kweon, B. S. \& Tyler, E., 1998. Plants in the Workplace. Environment and Behaviour, 30(3), pp. 261-281. 
Leaman, A. \& Bordass, B., 1999. Productivity in buildings: the 'killer' variables. Building

Research \& Information, 27(1).

Lee, J., Jones, P., Mineyama, Y. \& Zhang, X. E., 2002. Cultural differences in responses to a likert scale. Research in Nursing \& Health, 25(4), pp. 295-306.

Lerner, D. et al., 2001. The Work Limitations Questionnaire. Medical Care, 39(1), pp. 72-85.

Lohr, V., Pearson-Mims, C. \& Goodwin, G., 1996. Interior plants may improve worker productivity and reduce stress in a windowless environment. Journal of Environmental Horticulture, 14(2), pp. 97-100.

Mamuji, A. et al., 2004. Attentive Office Cubicles: Mediating Visual and Auditory. Nottingham, UbiComp.

Miller, N., Pogue, D., Gough, Q. \& Davis, S., 2009. Green buildings and productivity. Journal of Sustainable Real Estate, 1(1), pp. 65-89.

Moher, D. et al., 2010. Preferred reporting items for systematic reviews and meta-analyses: the PRISMA statement. International journal of surgery, 8(5), pp. 336-341.

Morrel-Samuels, P., 2002. Getting the truth into workplace surveys. Harvard Business Review. *Nieuwenhuis, M., Knight, C., Postmes, T. \& Haslam, S. A., 2014. The Relative Benefits of Green Versus Lean Office Space: Three Field Experiments. The Journal of Experimental Psychology: Applied, p. Advance Online Publication.

Oldham, G. R. \& Brass, D. J., 1979. Employee Reactions to an Open-Plan Office: A Naturally Occurring Quasi-Experiment. Administrative Science Quarterly, 24(2), pp. 267-284.

Oseland, N. \& Bartlett, P., 2000. Improving office productivity: A guide for business and facility managers. International Journal of Productivity and Performance Management, 49(3).

*Purdey B. \& Liefer. D., 2012. A preliminary study of cognitive failures in open plan offices. Facilities, 30(11), pp. 472-487.

Reeve, J., 2014. Understanding motivation and emotion. s.l.:John Wiley \& Sons.

Reilly, M. C., Zbrozek, A. S. \& Dukes, E. M., 1993. The Validity and Reproducibility of a Work Productivity and Activity Impairment Instrument. PharmacoEconomics, 4(5), pp. 353-365.

Roelofsen, E. \& Yue, T., 2017. Case Study: Is Holacracy for Us?. Harvard Business Review, April. 
Roelofsen, P., 2002. The impact of office environments on employee performance: The design of the workplace as a strategy for productivity enhancement. Journal of Facilities Management, 1(3), pp. 247-264.

Roijen, L. H.-v. \& Essink-Bot, M.-L., 2000. The Health and Labour Questionnaire, Rotterdam: Institute for Medical Technology Assessment.

*Saleem, A. et al., 2012. Impact of Interior Physical Environment on Academicians' Productivity in Pakistan Higher Education Institutes Perspectives. Iranian Journal of Management Studies, 5(1), pp. 25-46.

Schaufeli, W. \& Bakker, A., 2004. Utrecht Work Engagement Scale, Utrecht: Occupational Health and Psychology Unit - Utrecht University.

Seppänen, O., Fisk, W. J. \& Faulkner, D., 2004. Control of temperature for health and productivity in offices., San Francisco: Lawrence Berkeley National Laboratory. *Shiba, K., Nishimoto, M., Sugimoto, M., \& Ishikawa, Y., 2015. The association between meditation practice and job performance: A cross-sectional study. PLOS ONE, 10(5), pp. 1-13. Shikiar, R., Halpern, M., Rentz, A. \& Khan, Z., 2004. Development of the health and work questionnaire (HWQ): An instrument for assessing workplace productivity in relation to worker health. Work, 22(3), pp. 219-229.

Shimomitsu, T., 1998. Brief Job Stress Questionnaire, Tokyo: Japan Ministry of Health, Labour, and Welfare.

*Smith, A., Tucker, M. \& Pitt, M., 2010. Healthy, productive workplaces: towards a case for interior plantscaping. Facilities, 29(5), pp. 209-223.

*Tanabe, S.-i., Haneda, M. \& Nishihara, N., 2015. Workplace productivity and individual thermal satisfaction. Building and Environment, Volume 91, pp. 42-50.

Thomas, H. R., 2015. Benchmarking Construction Labor Productivity. Practice Periodical on Structural Design and Construction, 20(4).

Tiller, D., Wang, L. M., Musser, A. \& Radik, M., 2010. AB-10-017: Combined effects of noise and temperature on human comfort and performance (1128-RP).. ASHRAE Transactions, 116(2), pp. 522-540.

Tuomi, K. et al., 1998. Work Ability Index (WAI), Helsinki: Finish Institute of Occupational Health. 
*Vänni, K., Virtanen, P., Luukkaala, T. and Nygård, C.H., 2012. Relationship between perceived work ability and productivity loss. International journal of occupational safety and ergonomics, 18(3), pp.299-309.

Walden, J., Jung, E. H. \& Westerman, C. Y., 2017. Employee communication, job engagement, and organizational commitment: A study of members of the Millennial Generation. Journal of Public Relations Research, 29(2/3), pp. 1-17.

Walker, E. A., Petscavage-Thomas, J. M., Fotos, J. S. \& Bruno, M. A., 2017. Quality metrics currently used in academic radiology departments: results of the QUALMET survey. The British Journal of Radiology, 90(1071).

Wargocki, P. et al., 2000. The effects of outdoor air supply rate in an office on perceived air quality, sick building syndrome (SBS) symptoms and productivity. Indoor Air, 10(4), pp. 222236.

*Wiik, R., 2011. Indoor productivity measured by common response patterns to physical and psychosocial stimuli. Indoor Air, Volume 21, pp. 328-340.

Wohlers, C. \& Hertel, G., 2017. Choosing where to work at work-towards a theoretical model of benefits and risks of activity-based flexible offices. Ergonomics, 60(4), pp. 467-486.

Wyon, D. P., 2004. The effects of indoor air quality on performance and productivity.. Indoor Air, 14(s7), pp. 92-101.

Yoshitake, H., 1973. Occupational fatigue-approach from subjective symptom, Japan: The institute for science of labor. 